\title{
Atomic Energy Agency warns of imminent budget crisis
}

Vienna

DESPITE praise from leaders the world over for its nuclear safety efforts, the International Atomic Energy Agency (IAEA) is facing a financial crisis. The root of the problem is delinquent payments from member nations, not least of them the United States.

Hans Blix, director general of the IAEA, calls it "an absurdity" that the agency, praised for its efficiency and described by US President Ronald Reagan as "a model of effective international cooperation", should have a budget shortfall the agency. Its burden of operational safety visits to nuclear power plants has increased from two to twelve a year in the wake of the Chernobyl accident. Even steady payments will not be enough in the near future. "There will be a new enrichment plant coming on line in each of the maintain the level of quality of our safety inspections" when the budget is at zero growth. The agency will receive $\$ 137 \mathrm{mil}$ lions, in 1988, 0.6 per cent more than 1987.

Blix puts most of the blame for the agency's financial woes on the United States - which still owes $\$ 21$ million for 1987 - though he makes it clear that it is not the only country that pays late. The IAEA charter calls for each member to pay its dues in June, a deadline which "everybody ignores", says Blix. The IAEA has muddled through the past few years using early payments from some states and relying on a cash surplus that has now evaporated.

The difficulty with the United States results primarily from the bad reputation of international organizations in the in 1987 due to US tardiness.

The crunch comes at a critical time for next two years", says Blix. "We cannot

United States Congress, says Blix. Some groups, such as the United Nations Industrial Development Organization, have been hit harder than others. The IAEA has been affected despite having "friends" in the United States Congress and despite its value to a world made nervous by the Chernobyl catastrophe.

"The conclusion after Chernobyl", said Blix, "was that no accident resulting in radioactive release would be tolerable.

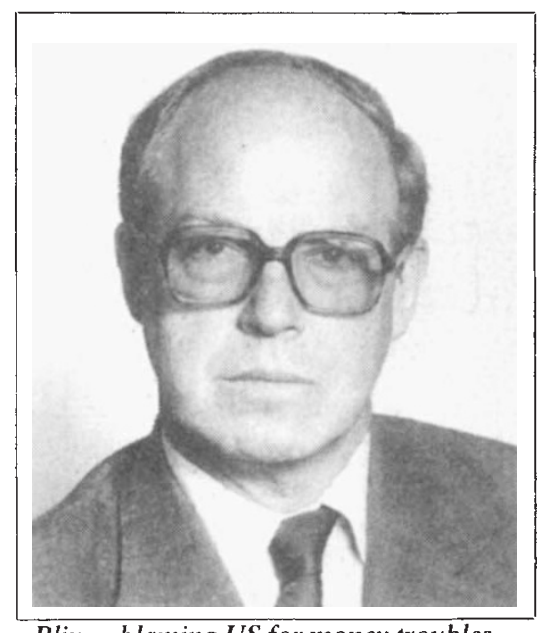

Blix - blaming US for money troubles

The member countries came to us to enforce this. But now they seem to be saying that this was only a temporary situation that we can go back to pre-1986 safety levels. Our view is that if you want a better safety effort, you have to pay for it." The IAEA does not have a very big stick with which to threaten late payers. The worst that can happen is that a member state two years in arrears loses its vote at meetings. Few countries have been deprived of their votes in the 30 -year history of the agency.

Steven Dickman

\section{Think-tank set up for British parliament}

\section{London}

SENIOR Conservative backbench Members of Parliament (MPs) are setting up an independent body to inform parliamentarians on scientific issues, supplementing inadequate information provided by the British government. The Science and Technology Information Service for Parliament (STISP) will advise MPs on matters likely to be debated in Parliament.

STISP is the brainchild of Sir Trevor Skeet, a Conservative MP and chairman of the all-party Parliamentary and Scientific Committee, a body comprising more than $200 \mathrm{MPs}$, peers and representatives from industry and research institutions.

In the absence of public money to support the venture, STISP will be supported by a charitable trust with funds from universities, research institutions and industry as well as members of the all-party committee itself. Enough money has been pledged or donated to run STISP for three years. In Skeet's opinion, however, STISP "should be publicly funded".

STISP has been more than two years in the making, during which time Skeet and his colleagues examined the Office of Technology Assessment in Washington, which advises the US Congress on scientific matter. STISP will be much more modest than its US counterpart. It will be run from a small office by a director, a chief executive and a small secretariat, working to an annual budget of about $£ 30,000$ to $£ 50,000$. Henry Gee

\section{Cambridge to host centre}

\section{London}

BRITAIN's Science and Engineering Research Council (SERC) has started the process of concentrating scientific research in interdisciplinary university research centres, secure in the knowledge that, despite reservations from sections of the academic community, the scheme has government approval. The site of the first centre, for research into high-temperature superconductivity (concentrating on small devices), announced last week, will be the Cavendish Laboratory at the University of Cambridge. Within the next four months, SERC wants to select sites for three more centres, to be operating by October.

The government is at present considering advice that academic science should be concentrated in a limited number of institutions; against this background, the process of bidding to host a research centre assumes considerable significance. How representative the first centre will be remains a matter for conjecture, given the unpredictable and fast-moving superconductor field.

Cambridge was one of 11 universities invited to bid to host the first centre. Its prize is a six-year grant of $£ 5.3$ million, with up to $£ 2.7$ million in the first two years, before an initial review. A second, review will be carried out after four years.

SERC expects to support the centre for 6-10 years. The joint SERC/DTI (Department of Trade and Industry) selection committee that considered the bids was said to have been influenced by the efforts Cambridge had made to achieve interdisciplinary collaboration.

The centre will have a permanent staff of four or five researchers, who will be employed by SERC, and a director yet to be chosen) who, will be an employee of the university. The bulk of the research will be done by staff seconded from the host university and elsewhere.

There will be five project coordinators, from the five departments that have already been collaborating on superconductor work at the university - chemistry, physics, engineering, Earth sciences and materials science and metallurgy. SERC stresses that funding for superconductor research will still be available to groups outside the research centre, for which $£ 2$ million has been committed in the current academic session.

Bids have been invited for centres in seven other topics, three of which will be selected in the current round of SERC grants. The topics include power applications of high-temperature superconductivity; surface science; molecular sciences; and process stimulation, integration and control.

Simon Hadlington 